\title{
PENINGKATAN KECAKAPAN HIDUP (LIFE SKILL) MELALUI PEMBIASAAN MENCUCI TANGAN \\ (Penelitian Tindakan Pada Anak Kelompok A TK Al- Fidaa Kec. Tambun Selatan Kab. Bekasi, Tahun Ajaran 2015)
}

\author{
Edi Mustofa \\ Pascasarjana Pendidikan Anak Usia Dini Universitas Negeri Jakarta \\ Jl. Rawamangun Muka, Jakarta Timur. 13220 \\ E-mail : edymustofaa24@yahoo.co.id
}

\begin{abstract}
Abstrak
Kecakapan Hidup (Life Skill) merupakan suatu kemampuan yang dimiliki seseorang untuk berperilaku positif, mengatur diri, dan terampil sosial. Pembiasaan mencuci tangan merupakan suatu kegiatan yang dilakukan dalam tindakan atau perilaku yang melatih anak memiliki keterampilan mencuci tangan dengan benar. Penelitian ini bertujuan untuk mengetahui peningkatan kecakapan hidup melalui pembiasaan mencuci tangan. Jenis penelitian yang digunakan adalah penelitian tindakan . Subjek dalam penelitian ini adalah anak Kelompok A TK Al- Fidaa Kec. Tambun Selatan Kab. Bekasi yang berjumlah 10 anak. Penelitian ini terdiri dari 2, siklus masingmasing siklus dilakukan sebanyak 8 kali pertemuan. Hasil penelitian menunjukkan bahwa melalui pembiasaan mencuci tangan dapat meningkatkan kecakapan hidup anak. Hasil penelitian kecakapan hidup anak pada pra siklus yaitu sebesar $40 \%$ dan meningkat pada siklus I menjadi $65 \%$ kemudian mengalami peningkatan menjadi $89 \%$ pada siklus II dengan kategori berkembang sangat baik.
\end{abstract}

Kata Kunci: Kecakapan Hidup, Pembiasaan Mencuci Tangan, Penelitian Tindakan

\section{Pendahuluan}

Anak usia dini adalah sosok individu sebagai makhluk sosiokultural yang sedang mengalami proses perkembangan yang sangat fundamental bagi kehidupan selanjutnya dan memiliki sejumlah karakteristik tertentu. Anak usia dini adalah suatu organisme yang merupakan satu kesatuan jasmani dan rohani yang utuh dengan segala struktur dan perangkat biologis dan psikologinya sehingga menjadi menjadi sosok yang unik. Anak usia dini mengalami suatu proses perkembangan yang fundamental dalam arti bahwa pengalaman perkembangan pada masa usia dini dapat memberikan pengaruh yang membekas dan berjangka waktu lama sehingga melandasi proses perkembangan anak selanjutnya. Setiap anak memiliki sejumlah potensi, baik potensi fisik-biologis, kognisi, maupun sosio-emosi. Anak yang sedang mengalami proses perkembangan sangat pesat sehingga membutuhkan pembelajaran yang aktif dan energik.

Di samping itu, program pengembangan TK harus dapat menanamkan dan menumbuhkan pembinaan perilaku dan sikap yang dilakukan melalui pendidikan kecakapan khusus yang memberi bekal dasar dan latihan yang dilakukan secara benar kepada anak didik tentang nilai-nilai kehidupan sehari-hari agar yang bersangkutan mampu, sanggup, dan terampil menjalankan kehidupannya yaitu dapat menjaga kelangsungan hidup dan perkembangannya, yang sering di sebut dengan life skill. 
Hal ini dipertegas oleh Larso (dalam Rakesh Sandhu) mengatakan: Life skills assist the students to face the challenges of everyday life. Life skill enhances the capabilities of the students so as to become healthy, responsible and productive citizens. Young people are considered the major agents in the ir own development, which means that they have the ability to create the supportive re lationships and communities they need to grow and thrive. ${ }^{1}$

Secara umum pendidikan berorientasi kecakapan hidup (Life Skill) bagi anak didik adalah sebagai bekal dalam menghadapi dan memecahkan problem hidup dan kehidupan, baik sebagai pribadi yang mandiri, warga masyarakat, maupun sebagai warga Negara.

Lebih jauh lagi Slamet (dalam Syarifatul Marwiyah) memberikan diskripsi tentang manfaat dari pendidikan yang berorientasi kepada kecakapan hidup sebagai berikut.

Pertama, peserta didik memiliki aset kualitas batiniyah, sikap, dan perbuatan lahiriyah yang siap untuk menghadapi kehidupan masa depan sehingga yang bersangkutan mampu dan sanggup menjaga kelangsungan hidup dan perkembangannya. Kedua, peserta didik memiliki wawasan luas tentang pengembangan karir dalam dunia kerja yang sarat perubahan yaitu yang mampu memilih, memasuki, bersaing, dan maju dalam karir. Ketiga, peserta didik memiliki kemampuan berlatih untuk hidup dengan cara yang benar, yang memungkinan peserta didik berlatih tanpa bimbingan lagi. Keempat, peserta didik memiliki tingkat kemandirian, keterbukaan, kerjasama, dan akuntabilitas yang diperlukan untuk menjaga kelangsungan hidup dan perkembangannya. Kelima, peserta didik memiliki kemampuan dan kesanggupan untuk mengatasi berbagai permasalahan hidup yang dihadapi. ${ }^{2}$

Berdasarkan hasil observasi awal di TK Alfida Tambun Selatan (Lampiran 1), peneliti menemukan kegiatan di TK tersebut belum mengembangkan pendidikan life skill. Hal ini dapat dilihat dari serangkaian kegiatan yang tidak mencerminkan keterampilan atau pembiasaan seperti keterampilan mencuci tangan yang seharusnya menggunakan sabun dan air mengalir, tetapi fenomena yang ditemukan di lapangan anak-anak mencuci tangan tidak dengan sabun dan air yang mengalir, tetapi anak hanya mencuci tangan disaat mau makan dengan air yang di tampung dengan ember.

Berdasarkan kenyataan dilapangan pada anak Kelompok A TK Al- Fidaa Kec. Tambun Selatan dengan jumlah 10 orang anak. Dari 10 orang anak tersebut terdapat 9 orang anak $(71 \%)$ belum mampu meningkatkan kecakapan hidup melalui pembiasaan mencuci tangan . Maka dalam penulisan penelitian ini penulis ingin meningkatkan kecakapan hidup (life skill) melalui pembiasaan mencuci.

Oleh karena itu, untuk memecahkan permasalahan di atas, peneliti mencoba mencari jalan keluar dengan upaya perbaikan pembelajaran melalui penelitian tindakan kelas, agar tercipta suasana pembelajaran yang menarik dan dapat

${ }^{1}$ Sandhu Rakesh. A Study of Skills of Pupil Teacher. Indian Journal of Fundamental and Applied Life Sciencees. 2014. H.389 
memotivasi anak untuk mengikutinya yaitu dengan pembiasaan mencuci tangan yang baik dan benar.

\section{Kajian Teoretik}

Menurut definisi World Health Organization (WHO), life skills atau keterampilan hidup adalah kemampuan untuk berperilaku yang adaptif dan positif yang membuat seseorang dapat menyelesaikan kebutuhan dan tantangan sehari-hari dengan efektif.

Kemudian Menurut Anwar ( dalam bukunya Pendidikan Anak Dini Usia) Keterampilan Kecakapan hidup meliputi minimal lima bagian; 1. Keterampilan mengenal diri (self awareness), yang juga sering disebut kemampuan personal (personal skill). 2 Kecakapan berfikir rasional (thingking skill). 3. Kecakapan sosial (sosial skill). 4. Kecakapan akademik (academic skill).5. Kecakapan vocasional (vocational skill). Kelima bidang tersebut, hendaknya diberikan secara simultan kepada anak didik, bahkan selama mereka masih berada pada pendidikan prasekolah dimana pada kondisi mereka masih merupakan masa pembentukan karakter yang akan mewarnai masa masa selanjutnya.

Selain itu life skill menurut Brolin dalam Anwar menjelaskan bahwa Kecakapan Hidup (life skill) constitute a continuum of knowledge and attitude that are necessary for a person to function effectifaly and to avoild interruptions of employment experience.

Albert Bandura mengemukakan bahwa pengajaran kecakapan hidup dibangun berdasarkan apa yang diketahui tentang bagaimana orang-orang muda belajar dari pengalaman mereka sendiri dan dari orang-orang di sekitar mereka, dari mengamati bagaimana orang lain berperilaku dan apa konsekuensi yang timbul dari perilaku.

Menurut Anwar Arsyad Kecakapan Hidup (life skill) adalah kecakapan yang dimiliki oleh seseorang untuk mau dan berani menghadapi problema hidup dan kehidupan secara wajar tanpa merasa tertekan, kemudian secara proaktif dan kreatif mencari serta menemukan solusi sehingga akhirnya mampu mengatasinya.

Pengertian lain mengatakan bahwa life skill are skills that enable a person to cope with the stresses and challenges of life. Satori dalam Anwar mengatakan pengembangan life skill bersumber pada (1) the world of work, (2) practical living skill, (3) personel growth and management, dan (4) social skills.

Dengan demikian kecakapan hidup (life skill) adalah suatu kemampuan yang dimiliki seseorang untuk berperilaku positif, mengatur diri, dan terampil sosial.

Pembiasaan mencuci tangan merupakan suatu kegiatan yang dilakukan dalam berpikir, bersikap dan bertindak sesuai dengan tujuan yang diinginkan yaitu tindakan atau perilaku melatih anak memiliki keterampilan mencuci tangan dengan benar. Hal ini dipertegas melalui Teori-teori behaviorist dari Thorndike mengemukakan bahwa cara belajar pada hewan dan manusia pada dasarnya berlangsung menurut prinsip-prinsip yang sama. Belajar dapat terjadi kalau ada stimulus. 


\section{Metode Penelitian \\ Tipe penelitian}

Tipe penelitian ini digunakan metode penelitian tindakan (action reserch) untuk mendapatkan hasil yang akurat, alur penelitian tindakan ini mengacu pada model penelitian tindakan yang dikemukakan oleh Kemmis danTaggart. Kemmis dan Taggart menggambarkan action research sebagai suatu spiral langkah-langkah, yang masing-masing langkah mempunyai 3 tahap, yaitu: (1) planning, (2) Acting and Observing, (3) Reflecting.

\section{Subjek Penelitian}

Subjek dalam penelitian ini adalah Anak kelompok A TK Alfida Kecamatan Tambun Selatan, semester ganjil Tahun Pelajaran 2014/2015 yang berjumlah 10 orang anak.

\section{Tempat dan Waktu Penelitian}

Penelitian ini dilaksanakan di TK Alfida Kecamatan Tambun Selatan Bekasi. Waktu Penelitian Penelitian dilaksanakan, dimulai pada bulan Febuari sampai dengan April 2015.

\section{Data dan Sumber Data}

Data yang dikumpulkan dalam penelitian ini adalah :

1) Catatan lapangan

2) Dokumentasi sumber data adalah anak Kelompok A TK Al Fidaa

3) Siswa yang diambil sebagai subjek penelitian adalah anak- anak kelompok A TK Al Fidaa.

\section{Instrumen Penelitian} berikut:

Pengumpulan data yang diperlukan dalam peneltian ini dilakukan sebagai

\section{A. Prosedur Penelitian Tindakan}

Berdasarkan model penelitian Kemmis dan Tanggart maka langkahlangkahnya sebagai berikut: planning, acting and observing dan reflecting. Refleksi dilakukan sebagai bahan dasar bagi pengembangan atau perbaikan pada siklus selanjutnya. Jumlah siklus dapat ditambah sesuai dengan peningkatan yang dicapai dalam proses pembelajaran.

\section{Kegiatan Pra Penelitian}

Persiapan pra penelitian dilakukan sebelum melaksanakan kegiatan di siklus I yang mana pra penelitian adalah salah satu cara untuk mengetahui rendahnya kecakapan hidup anak di Kelompok A TK All Fidaa Tambun Selatan

\section{Siklus I}

\section{a. Perencanaan (Planning)}

Rencana tindakan merupakan tindakan yang tersusun dari segi definisi harus mengarah pada tindakan, yaitu bahwa rencana itu harus memandang kedepan. Rencana tindakan sebaiknya dibuat fleksibel, sehingga memungkinkan perubahan selama tindakan berlangsung hal ini mengingat kondisi lapangan tidak dapat diprediksi, sehingga adaptasi lapangan masih perlu dilakukan.

b. Pelaksanaan Tindakan (Acting) dan Pengamatan (Observasi)

1. Pelaksanaan Tindakan

Tahap ini merupakan tahap penting atau inti dari seluruh rencana yang telah ditentukan peneliti dan kolaborator memfokuskan dalam mengimplementasikan pembiasaan mencuci tangan dalam 
meningkatkan kecakapan hidup anak dilihat dari: berperilaku positif, memngatur diri,dan kecakapan sosial anak.

\section{a. Pengamatan (Observasi)}

Peneliti melakukan pengamatan tidak hanya ketika pelaksanaan tindakan namun terhadap semua aktivitas anak selama berada disekolah sesuai dengan indikator-indikator yang telah disepakati. Observasi bebas dilakukan dengan mencermati dan mencatat kejadian-kejadian penting selama proses pembelajaran berlangsung. Obsevasi dilaksanakan untuk mengamati proses kecakapan hidup anak sebelum, saat sedang, dan setelah pelaksanaan tindakan secara keseluruhan serta hal-hal yang terkait lainnya.

\section{b. Refleksi (Reflecting)}

Refleksi adalah mengingat dan merenungkan kembali suatu tindakan persis yang telah dicatat dalam observasi. Refleksi dilakukan untuk mengevaluasi pelaksanaan tindakan, refleksi dilakukan bersama guru yang terlibat dan pimpinan lembaga guna mengevaluasi tindakan dan mendiskusikan rencana berikutnya. Dalam refleksi juga dilakukan untuk menganalisis dan mengintepretasikan berbagai catatan kejadian serta mengevaluasi seluruh kegiatan selama siklus I berlangsung. Serta mencari faktor penyebab tidak tercapainya tujuan pembelajaran yang telah dirumuskan sebelumnya.

Pada penelitian ini, nantinya akan dilakukan refleksi secara keseluruhan dari kegiatan pembelajaran dengan menggunakan pembiasaan mencuci tangan yang telah dilaksanakan, apakah tindakan yang diberikan telah mencapai indikator-indikator yang ditetapkan atau belum, sehingga nantinya aka ada perbaikan guna melanjutkan ke siklus selanjutnya.

\section{Siklus II}

Siklus II dilaksanakan dengan melakukan perubahan pada bagianbagian tertentu yang didasarkan pada refleksi siklus I, sesuai dengan rencana pembelajaran yang telah disusun. Sasaran kegiatan adalah untuk memperbaiki aspek-aspek yang dinilai belum berhasil pada siklus I. Hasil yang didapat pada siklus II dianalisa dan dibandingkan dengan siklus I kemudian digunakan untuk mengukur keberhasilan pelaksanaan siklus II. Langkah yang digunakan sama halnya dengan yang dilakukan pada siklus.

\section{Analisis Data}

Teknik analisis data yang dilakukan dalam penelitian ini adalah melalui dua cara yaitu analisis data kualitatif dan analisis data kuantitatif.

\section{Analisis Kualitatif}

Analisis data kualitatif yaitu menganalisis data yang terjadi dalam proses pembelajaran melalui pembiasaan mencuci tangan, sejak pelaksanaan observasi awal hingga pelaksanaan siklus dengan prosedur pelaksanaan meliputi perencanaan, pelaksanaan, observasi dan refleksi. Data yang muncul dari data kualitatif berwujud kata-kata bukan rangkaian angka. Analisis data kualitatif menggunakan teknik menurut Miles dan Huberman yang terdiri dari: data reduction, data display, dan conclusing drawing/verification. 


\section{Analisis Kuantitatif}

Data kuantitatif yaitu skor tes yang diperoleh anak dalam kegiatan dengan menggunakan pembiasaan mencuci tangan yang dinilai oleh observer melalui instrumen berupa lembar observasi. Skor tes yang dimaksud yaitu skor yang diperoleh pada saat assesmen awal maupun tes yang diambil diakhir siklus. Data kuantitatif dianalisis dengan menggunakan statistik deskriptif yang disajikan dalam bentuk tabel/grafik. Untuk melihat hasil tindakan digunakan studi proporsi nilai rata-rata sebelum dan sesudah mendapat tindakan.

Untuk melihat kenaikan rata-rata pencapaian kecakapan hidup anak melalui pembiasaan mencuci tangan dibandingkan dengan skor target, digunakan studi proporsi nilai rata-rata anak sebelum mendapat perlakuan dan setelah mendapat perlakuan.

Selain itu untuk memudahkan menginterpretasikan hasil, maka jumlah hasil dengan rumus sebagai berikut :

$$
\mathrm{P}=\frac{\sum X}{N}
$$

\section{Keterangan:}

$\mathrm{P} \quad=$ Proporsi kecakapan hidup anak

$\sum \mathrm{x} \quad=$ Skor yang diperoleh

$\mathrm{N} \quad=$ Jumlah Skor maksimal

\section{Persentase kenaikan $=$ Persentase siklus $\mathbf{I}-$ Persentase pra penelitian}

Keberhasilan tindakan disimpulkan dengan menggunakan analisis, dinyatakan berhasil jika rata-rata kelas persentese penilaian kecakapan hidup anak diatas $71 \%$ atau sebanyak 7 orang anak dari 10 orang anak meningkat setelah diberikan tindakan melalui pembiasaan mencuci tangan. Untuk membuktikan persentase kenaikan keberhasilan penelitian dengan merujuk pada deskripsi hasil penelitian Mills yang menunjukkan pada angka $71 \%$.

\section{Hasil Dan Pembahasan}

Penelitian tindakan ini dilaksanakan di Kelompok A TK Al Fidaa Tambun Selatan Bekasi dengan jumlah siswa sebanyak 10 anak. Penelitian tindakan ini dilakukan sebanyak 2 siklus. Secara garis besar data hasil penelitian adalah sebagai berikut : Hasil kecakapan hidup anak pada pra siklus yaitu sebesar $40 \%$ dan meningkat pada siklus I menjadi $65 \%$ kemudian mengalami peningkatan menjadi $89 \%$ pada siklus II dengan kategori berkembang sangat baik.

Data peningkatan kecakapan hidup anak kelas 1 SD N 14 Lubai dapat disajikan sebagai berikut : 
Tabel 4. 21 Data Kecakapan hidup Anak Kelompok A TK Al Fidaa

\begin{tabular}{|c|c|c|c|}
\hline Tahapan & Pra Siklus & Siklus I & Siklus II \\
\hline Rata - rata & 40 & 65 & 89 \\
\hline Peningkatan & - & 25 & 24 \\
\hline
\end{tabular}

Dari tabel diatas, dapat dilihat bagaimana peningkatan kecakapan hidup anak Kelompok A TK Al Fidaa. Pada siklus II rata- rata TCP anak telah mencapai kriteria keberhasilan yang ditentukan oleh peneliti dan kolabolator sehinga penelitian tindakan ini dikatakan telah berhasil.

\section{Kesimpulan} berikut:

Berdasarkan temuan dan pembahasan, penelitian ini menyimpulkan sebagai

1. Proses peningkatan kecakapan hidup (life skill) melalui pembiasaan mencuci tangan dapat meningkatkan tiga aspek keterampilan personal, pengaturan diri dan keterampilan sosial.

2. Pembiasaan mencuci tangan dapat meningkatkan kecakapan hidup (life skill) anak, terlihat adanya peningkatan persentase keterampilan setiap responden dari sebelum tindakan, tindakan siklus I sampai pada siklus ke II. Hal tersebut dapat dilihat dari persentase rata-rata keterampilan anak pada tahap prasiklus berjumlah $43 \%$ dan setelah diberikan tindakan pada siklus I rata-rata kecakapan hidup (life skill) anak mencapai kemudian meningkat pada siklus I hingga mencapai $65 \%$ selanjutnya pada siklus ke II, rata-rata kecakapan hidup (life skill) anak meningkat lagi hingga mencapai $89 \%$.

\section{Daftar Pustaka}

AF Widmer, 2000. Replace Hand Washing with Use of a Waterless Alcohol Hand $R u b$ ?, Clinical Infectious Disease

Anwar. 2006. Pendidikan Kecakapan Hidup: Konsep dan Aplikasi. Alfabeta : Bandung.

Arsyad, A. 2007.Media Pembelajaran. Jakarta: Raja Grafindo Persada Piran \& Sasonohardjo, 2002. Media Pembelajaran. Jakarta: Lembaga Administrasi Negara

Asra, et., al.Komputer Dan Media Pembelajaran Di SD. Jakarta:DIREKTORAT JENDERAL PENDIDIKAN TINGGI. DEPARTEMEN PENDIDIKAN TINGGI, 2007.

David Hopkins, A Teacher Guide to Classroom Research. Third Edition. philadelpia: open University Press, 1993.

Depkes RI. Panduan Manajemen PHBS Menuju Kabupaten/Kota Sehat. Jakarta: Depkes RI; 2008.

Diadopsi dari WHO guidelines on hand hygene in health care : First Global Patient Safety Challenge, World Health Organization, 2009.

Firman Eko, dkk. Hubungan Peran Orang TuaDalamPromosiKesehatanDenganPelaksanaanCuciTanganPadaAnakU siaPrasekolah.http://www.qjournal.co.id/paper-285-hubungan-peranorang-tua-dalam-promosi-kesehatan-dengan-pelaksanaan-cuci-tanganpada-anak-usia-prasekolah.html. pukul 20:34. 31/05/2014. 
Linda, dkk, Panduan Pencegah Infeksi Untuk Fasilitas Pelayanan Kesehatan Dengan Sumber Daya Terbatas, (Yayasan Bina Pustaka Sarwono Prawirohardjo bekerja sama dengan JNPKKR/POGI dan JHPIEGO (Program Mnh \& Starh). Jakarta, 2010.

Milles, M.B. and Huberman, M.A. 1984. Qualitative Data Analysis. London: Sage Publication

Nur Aisah, Meningkatkan Kemampuan Mencuci Tangan Melalui Metode Demonstrasi. Kelompok B Di Tk Unggulan Terpadu Al Kautsar Mojokerto, Jurnal Ilmiah, Universitas Negeri Surabaya, Surabaya). http://jurnal.untan.ac.id/index.php/jpdpb/article/viewFile/4203/4220 diakses pada 19:57 31/05/2014. 